\title{
THE RELATIONSHIP BETWEEN ORGANIZATIONAL CULTURE AND PUBLIC RELATIONS IN BUSINESS ORGANIZATIONS
}

\author{
Edit Terek STOJANOVIĆ(D) ${ }^{*}$, Marko VLAHOVIĆ ${ }^{1}$, Milan NIKOLIĆ ${ }^{1}$, \\ Siniša MITIĆ ${ }^{2}$, Zoran JOVANOVIĆ ${ }^{3}$ \\ ${ }^{1}$ Technical Faculty "Mihajlo Pupin", University of Novi Sad, Zrenjanin, Serbia \\ ${ }^{2}$ Faculty of Technical Science, University of Novi Sad, Novi Sad, Serbia \\ ${ }^{3}$ Belgrade Faculty of Management in Zaječar, John Naisbitt University, Zaječar, Serbia
}

Received 24 December 2019; accepted 04 May 2020

\begin{abstract}
The study presents the results of the impact of organizational culture on public relations in business organizations. The data were obtained from a survey of 415 respondents from 93 companies in Serbia. The following statistical methods were used: descriptive statistics, correlation analysis, regression analysis and hierarchical regression analysis. Some of the most important conclusions of the research follow: In most cases, the organizational culture dimensions have a statistically significant and positive influence on the communication models of public relations (CMPR) dimensions and the organization - public relations (OPR) dimensions; A favorable organizational culture (represented through the favorable values of the organizational culture dimensions) has a positive impact on two-way models of communication, especially the symmetrical model, as well as on most of the OPR dimensions. On the other hand, an unfavorable organizational culture encourages one-way communication and the organization's orientation solely for its own benefit; The Power Distance dimension acts in contrast to the other dimensions of organizational culture: high power distance impedes two-way communication and promotes the utility of the company, all of which causes public distrust and dissatisfaction.
\end{abstract}

Keywords: organizational culture, public relations models, organization - public relationships, the organization's national origin, Serbia.

JEL Classification: D23, D83.

\section{Introduction}

Organizational culture pervades all the actions of a company and its influence is very strong. Organizational culture has an influence on every form of business life. Culture represents what a company is itself (Pacanowsky \& O’Donnell-Trujillo, 1982). Hofstede (1991) calls culture software of the mind which differentiates the representatives of different organizations. Successful managers should exert influence on employees so that organizational culture can

${ }^{\star}$ Corresponding author. E-mails: edit@tfzr.uns.ac.rs; terekedita@gmail.com 
succeed in bringing together the beliefs and standpoints of the workers of an organization (Weihrich \& Koontz, 1998). Supervisors have to know the meaning of a range of different skills that is needed in order to be prosperous in their work so they can make decisions on an acceptable and delicate cultural level (Javidan \& House, 2001).

The results of an organization are associated with organizational culture (House et al., 2004). There are many publications about the importance of organizational culture, and numerous studies have been carried out indicating its significance, how it operates, adjusts, evolves, and what influence has it on the workers of a company (Hofstede, 1991, 1998, 2001; Deal \& Kennedy, 1982; Schein, 1985; O’Reilly et al., 1991; Calori \& Sarnin, 1991; Kotter \& Heskett, 1992; Ogbonna \& Harris, 2000; House et al., 2004).

Likewise, organizational culture is related to the function of PR in companies. This connection is natural because PR should represent the organization's conscience (Black, 2003), and organizational culture certainly shapes the work style and life of the organization. So, organizational culture influences public relations (Harris et al., 1999; Curtin, 2008; Johnston \& Everett, 2012; Meng, 2014; Vance et al., 2016; Men \& Jiang, 2016). It should be borne in mind that societal culture has an influence on public relations (Martinelli \& Erzikova, 2017; Dhanesh \& Sriramesh, 2018; Verhoeven et al., 2018; Chen et al., 2020; Bhalla \& Overton, 2019).

The aforementioned statements undoubtedly confirm the existence of the influence of organizational culture on PR in organizations. However, it seems that there are not enough studies which address the impact of organizational culture on public relations. The aim of this study is to explore the impact of particular dimensions of organizational culture on particular dimensions of PR. In addition, as representative aspects of PR, in this study, CMPR dimensions and OPR dimensions are also considered. The survey was conducted in companies in Serbia. The study also analyzes the company's national origin as a moderator, which will enable us to see the differences in the way in which organizational culture operates in relation to public relations in domestic (Serbian) and foreign companies (operating in Serbia). Determining the observed relationships and moderating effects, as well as understanding these relationships, profiles opportunities to improve the work of Public Relations (PR) functions in organizations. Finally, all this contributes to creating more favorable conditions for achieving better business results.

The study is structured by initially providing an introduction followed by theory and hypothesis (a theoretical overview of the fields of interest in the work after which two hypotheses and one research question were set). The survey method was then presented with a description of the survey instruments (measures), participants and data collection procedure. A summary of the results is then presented followed by the disccusion of these results. Finally, the conclusion and an overview of the used references are given.

\section{Theoretical background and hypothesis}

\subsection{Organizational culture}

Culture represents a collective-directed sensation, it refers to common meanings, and cultural norms manifest themselves in the style of artifacts (House et al., 1997). Cultural vari- 
ables have an impact on the social aspect because the members of the collective share a set of values and social identity. Additionally, attitudes have a great connection with the cultural, professional and educational background of employees, rooted in the company to which employees belongs. Because of a worldwide integration great significance is given to the comprehension of national and organizational culture (House et al., 2001). Culture is not the only factor affecting the behavior of people. Although the cultural dimension can be determined at the level of culture, it does not necessarily mean that it will inevitably be reflected in the behavior of each individual member of that culture (Hofstede, 1991). In other words, the analysis of the level of culture reflects the basic efforts of the country from which it originates, but does not foresee individual behavior. However, a significant part of the value of a national community is common to all its individuals, which is why it is called national culture. It is an outstanding aspect that identifies the profile of individual principles and also the beliefs of the organizational culture of the organizations that operate within its framework.

Organizational culture is in direct association with worker contentment (Moynihan \& Pandey, 2007). Companies with a high number of content employees are likely to be more efficient than companies with a few content workers. There is a very important study in this area (Judge et al., 2001) that presents that the determinants related to organizational culture and individual factors have the biggest influence.

\subsection{Public relations models}

One of the tasks of the PR service in organizations is to manage the communication which takes place between the organization and the target public. In doing so, there are various ways to manage this communication, referred to as public relations work models.

According to Grunig and Hunt, (1984), there are four typical PR communication service models:

1. Public information (one-way communication). Here, communication moves in the direction organization - public, and feedback is not considered. The truthfulness of the information being posted is important. This is especially true in cases of unfortunate events, campaigns for some medical issues, etc.

2. Press agentry/publicity (one-way communication). An idea, product or person is promoted through publicity. Often, the truth is not so important, so exaggeration may arise. Feedback is not considered.

3. Two-way asymmetrical (two-way communication). This model is based on persuasion, such as buying or voting. Although the organization takes public opinion into account, this is primarily to meet its own goals. Information is collected from the public, only to formulate messages that will most easily convince the public of what the organization wants to achieve. Here, feedback from the public is not used to correct the goals and strategies of the organization.

4. Two-way symmetrical (two-way communication). The organization enters into dialogue with the public. Both sides adjust their attitudes, change their behavior and come to a mutual understanding. This result in appropriate solutions for both the organization and the public, and the benefits are mutual. 
In the first and second models, communication is always one-way: direction organization - public. These models can be described as involving speech rather than listening. In the third and fourth models, communication is two-way: direction organization - public and public - organization. According to Grunig and Hunt (1984), only a double symmetrical model is completely correct and only through it can top results be achieved in the field of PR. This model is ideal and has the most pronounced ethical features, since power and influence are equally distributed (Windahl et al., 2009). Wilcox and Cameron (2009) also point to the significance of feedback and the greater efficiency of two-way communication in relation to one-way communication. However, Black (1993) states that it is achievable to accomplish high-quality PR with the application of any of these four models. Also, according to the same author, it is possible that the best PR programs use elements from all four models. Likewise, at different times, different models can be effective.

\subsection{Organization - public relationships}

The public have started to pay increasing consideration to companies, in order to get something for the society in return (Gordon, 2011). Stakeholders estimate organizations in terms of how they relate to ethical issues, environmental decisions and the wider community. Situation like this is common in every country. Companies have become responsible for society and the preservation of the environment. The companies themselves notice these tendencies and have become familiar about their wide impact on the community.

In that sense, companies should attach particular importance to business ethics and corporate social responsibility, which will in turn contribute to increasing the level of trust in the organization (Wilcox \& Cameron, 2009). Berger and Reber (2006) consider the main task of public relations that of building and defending the reputation of the organization, as well as of establishing strong links in the relation organization - target public.

Likewise, public relations have a very significant strategic component in organizations in the US and Western Europe (Grunig et al., 1995). In these countries, public relations make up the bulk of organizational communications, through which organizations form strong relationships with key audiences, which certainly contributes greatly to the achievement of their mission and strategic goals. In the reference (Penning, 2011), examined was how stockholders (investors) value public relations communication. It was found that investors value information from PR professionals (directly from a company) more than that from news media and other sources.

\subsection{Societal culture, organizational culture and PR}

The Global Public Relations Framework indicates that PR practice is influenced by the political system, economic system, media, societal and organizational culture and activism (Sriramesh \& Verčič, 2009, 2019). Among cultural factors, public relations practice can be influenced by: the level of public stratification, uncertainty acceptance, role identification that is established on gender, collectivism, power distance, long or short-term orientation to life, mutual trust, as well as certain unique characteristics. All these cultural and other factors of the global public relations framework, as well as the interconnections between them, 
must be taken into account when conducting public relations practice research (Dhanesh \& Duthler, 2019). Similarly, Erzikova, Waters and Bocharsky (2018) indicate that there are mutual influences between reporters, PR practitioners, internal factors and external factors. According to the same authors, it is important to study these influences in different countries and cultural settings.

Dhanesh and Sriramesh (2018) state that multinational corporations must certainly take into account the characteristics and specificities of the culture of the host country (if they are to maintain their reputation and business results). This is especially pronounced in the field of crisis communication. Finally, a survey conducted in companies in Russia (Lumbar Globočnik et al., 2019), shows the impact of societal culture on PR strategies. More specifically, societal culture has a considerable impact on two-way symmetrical, asymmetrical, ethical, unethical, interpersonal, and mediated communication and conservation strategies, while influences do not exist on one-way communication and cultural interpretation.

What is most important for this research are the references that deal with the direct effects of organizational culture on certain aspects of public relations. According to Sriramesh et al. (1996), evidence has been identified that indicates the link between the attitude of the organizational culture to PR and the communication practices of an organization. In PR it is shown that culture is neither necessary nor sufficient for excellence. Nevertheless, excellence in PR will expectedly exist in organizations with participatory culture, while in authoritarian culture excellence is most likely to be absent.

Twenty years later, in a study carried out by Erzikova and Berger (2016) the influence of organizational culture on public relations was confirmed. This research found the existence of male-dominated social, professional and gender stereotypes. Yeo and Pang (2017) wrote about the relationship between organizational culture and PR. Their study aims to understand the role of cultural values and their impact on public relations in Singapore. Because Singapore displays a hybrid culture their research aims to see the way that multiculturalism operates, discovers whether the values that have a bigger impact on organizational communication mirror the ones in an individualistic or collectivist society. The relationship between organizational culture and PR was also established by the authors Thurlow et al. (2017). In their research, they found that excellence in an organizational context may serve to evaluate the performance of public relations. Accordingly, Meng and Berger (2019) found that there is a strong influence of leader achivement and organizational culture on PR managers' work commitment, trust and job satisfaction.

According to the previous discussions, the hypotheses that are set in this study are:

$\mathrm{H1}$ : A significant interaction can be found between the organizational culture dimensions and the CMPR dimensions and the OPR dimensions.

$\mathrm{H} 2$ : A significant predictive effect can be found of the organizational culture dimensions on the CMPR dimensions and the OPR dimensions.

The study also examines the moderating effect of the organization's national origin. So, one research question is set:

RQ: Is there a moderating influence of the organization's national origin on the relationship between the organizational culture dimensions and the CMPR dimensions and the OPR dimensions? 


\section{Methodology}

\subsection{Research instruments}

Organizational Culture. In this study, as an instrument for measuring organizational culture, the GLOBE project was used (House et al. 1999, 2002, 2004). The GLOBE project set up the dimensions of organizational culture that can be viewed in two ways: determining the real state ("state as it is") and determining the desirable state ("state as it should be"). In this research, the first part of the questionnaire for the measurement of organizational culture was used (the state "as is"). This questionnaire comprises 34 questions with a seven-point Likert scale. The completed questionnaires were handled in line with the GLOBE Syntax. The GLOBE measures nine dimensions of organizational culture: Uncertainty Avoidance, Future Oriented, Power Distance, Institutional Collectivism (Collectivism 1), Humane Orientation, Performance Orientation, In-Group Collectivism (Collectivism 2), Gender Egalitarianism and Assertiveness (House et al., 2004; Javidan et al., 2004). A brief description of the meaning of these dimensions can be seen in the study (Rajković et al., 2020).

Public Relations Models. The instrument given in the paper (Grunig et al., 1995) was applied for measuring CMPR. The questionnaire consists of sixteen items distributed in four dimensions (Public Information, Press Agentry, Two-way Asymmetrical and Two-way Symmetrical). Answers by the respondents were given on a seven-point Likert scale. This way of measuring models of public relations and putting them in relation to other variables can be found in a reference (Vasquez \& Taylor, 2000).

Organization - Public Relationships. By the PR Relationship Measurement Scale (Hon \& Grunig, 1999), examined were the relations between the organization and public. The questionnaire comprises thirty items arranged in six dimensions (Control Mutuality, Trust, Commitment, Satisfaction, Exchange Relationship and Communal Relationship). The respondents gave their answers on a seven-point Likert scale. Hon and Grunig (1999) consider this concept to be a firm sign of the effectiveness of PR.

\subsection{Sample}

The sample was collected in organizations in Serbia. The survey was conducted by the respondents completing the questionnaires. In doing so, Google surveys were used through social networks, WhatsApp and Viber applications. Prior to submitting the questionnaire electronically, respondents were informed of the content and objectives of the survey. Direct interviews were also made with PR and marketing practitioners in Serbian organizations. PR and marketing practitioners were selected as respondents because the research is related to the field of PR, which is exactly what the respondents do professionally in their day-to-day business. In addition, these respondents have insight into the organization's work methods and value systems. Because of this, respondents, as experts, were able to objectively express their judgment about the state of organizational culture, models of public relations and OPR, in their organization.

A total of $\mathrm{N}=415$ valid questionnaires were collected from 93 organizations. There were in total $60.7 \%$ respondents who work in Serbian organizations and 39.3\% who work 
1634 E. T. Stojanović et al. The relationship between organizational culture and public relations in business...

in foreign companies that operate in Serbia. Most of the respondents were women (61.2\%). 35.81 years was the average age of the respondents. Out of the total number of respondents, $35 \%$ were at an operational position, $37 \%$ were at the managerial position, while $28 \%$ were at top management positions. $86.5 \%$ of the $\mathrm{PR}$ and marketing practitioners were employed by private organizations, while $13.5 \%$ of them were employed by state-owned organizations.

\section{Results}

\subsection{Descriptive statistics}

Table 1 presents the descriptive statistics and refer to all the dimensions of the observed questionnaires (Organizational Culture, Models of Public Relations, the PR Relationship Measurement Scale). Full names, short names of the dimensions, the mean value, the standard deviation, and Cronbach's alpha can be found in Table 1 (in this case from 0.703 to 0.944 ).

Table 1. Mean values, standard deviation and Cronbach's alpha for all dimensions

\begin{tabular}{|l|c|c|c|c|c|c|c|}
\hline \multicolumn{1}{|c|}{ Dimensions } & $\begin{array}{c}\text { Short } \\
\text { name }\end{array}$ & No. & Min. & Max. & Mean & $\begin{array}{c}\text { Stand. } \\
\text { Dev. }\end{array}$ & $\begin{array}{c}\text { Cron. } \\
\alpha\end{array}$ \\
\hline Uncertainty Avoidance & CUL1 & 415 & 1.00 & 7.00 & 3.6305 & 1.26539 & .703 \\
\hline Future Oriented & CUL2 & 415 & 1.00 & 7.00 & 4.4434 & 1.46105 & .725 \\
\hline Power Distance & CUL3 & 415 & 1.00 & 7.00 & 4.0715 & 1.47150 & .717 \\
\hline Collectivism 1 & CUL4 & 415 & 1.00 & 7.00 & 4.5343 & 1.18421 & .764 \\
\hline Humane Orientation & CUL5 & 415 & 1.00 & 7.00 & 4.8157 & 1.34171 & .855 \\
\hline Performance Orientation & CUL6 & 415 & 1.00 & 7.00 & 4.6066 & 1.54177 & .885 \\
\hline Collectivism 2 & CUL7 & 415 & 1.00 & 7.00 & 4.8547 & 1.46493 & .704 \\
\hline Gender Egalitarianism & CUL8 & 415 & 1.00 & 6.75 & 3.8946 & .91479 & .837 \\
\hline Assertiveness & CUL9 & 415 & 1.50 & 7.00 & 4.8398 & 1.29808 & .780 \\
\hline Public Information & MOD1 & 415 & 1.00 & 7.00 & 3.7265 & 1.24002 & .756 \\
\hline Press Agentry & MOD2 & 415 & 1.00 & 7.00 & 4.5928 & 1.32235 & .799 \\
\hline Two-way Asymmetrical & MOD3 & 415 & 1.00 & 7.00 & 4.0331 & 1.36244 & .785 \\
\hline Two-way Symmetrical & MOD4 & 415 & 1.00 & 7.00 & 4.2163 & 1.31844 & .834 \\
\hline Control Mutuality & REL1 & 415 & 1.00 & 7.00 & 4.8477 & 1.41132 & .927 \\
\hline Trust & REL2 & 415 & 1.00 & 7.00 & 5.1562 & 1.33977 & .926 \\
\hline Commitment & REL3 & 415 & 1.00 & 7.00 & 5.1667 & 1.21598 & .911 \\
\hline Satisfaction & REL4 & 415 & 1.00 & 7.00 & 5.1219 & 1.28427 & .944 \\
\hline Exchange Relationship & REL5 & 415 & 1.00 & 7.00 & 4.1916 & 1.25940 & .793 \\
\hline Communal Relationship & REL6 & 415 & 1.00 & 7.00 & 5.0694 & 1.33500 & .826 \\
\hline & & & & & & & \\
\hline
\end{tabular}

\subsection{Correlation analysis}

Table 2 presents the coefficients of correlation between the organizational culture dimensions and the CMPR dimensions and the OPR dimensions. Pearson's correlation was used. 
Table 2. Coefficients of correlation between the organizational culture dimensions and the CMPR dimensions and the OPR dimensions

\begin{tabular}{|l|c|c|c|c|c|c|c|c|c|c|}
\hline & MOD1 & MOD2 & MOD3 & MOD4 & REL1 & REL2 & REL3 & REL4 & REL5 & REL6 \\
\hline CUL1 & -.067 & .034 & $.230^{* *}$ & $.327^{* *}$ & $.376^{* *}$ & $.413^{* *}$ & $.411^{* *}$ & $.426^{* *}$ & .005 & $.363^{* *}$ \\
\hline CUL2 & $-.196^{* *}$ & -.057 & $.334^{* *}$ & $.424^{* *}$ & $.529^{* *}$ & $.556^{* *}$ & $.513^{* *}$ & $.539^{* *}$ & -.011 & $.443^{* *}$ \\
\hline CUL3 & $.247^{* *}$ & $.266^{* *}$ & -.067 & $-.224^{* *}$ & $-.333^{* *}$ & $-.320^{* *}$ & $-.265^{* *}$ & $-.282^{* *}$ & $.191^{* *}$ & $-.346^{* *}$ \\
\hline CUL4 & -.064 & -.004 & $.318^{* *}$ & $.453^{* *}$ & $.526^{* *}$ & $.529^{* *}$ & $.514^{* *}$ & $.532^{* *}$ & -.040 & $.424^{* *}$ \\
\hline CUL5 & $-.163^{* *}$ & $-.099^{*}$ & $.248^{* *}$ & $.432^{* *}$ & $.611^{* *}$ & $.596^{* *}$ & $.519^{* *}$ & $.578^{* *}$ & -.051 & $.511^{* *}$ \\
\hline CUL6 & $-.157^{* *}$ & $-.106^{*}$ & $.253^{* *}$ & $.428^{* *}$ & $.631^{* *}$ & $.631^{* *}$ & $.548^{* *}$ & $.578^{* *}$ & -.066 & $.525^{* *}$ \\
\hline CUL7 & $-.162^{* *}$ & $-.108^{*}$ & $.292^{* *}$ & $.483^{* *}$ & $.657^{* *}$ & $.660^{* *}$ & $.599^{* *}$ & $.627^{* *}$ & -.077 & $.588^{* *}$ \\
\hline CUL8 & -.040 & -.054 & $.200^{* *}$ & $.206^{* *}$ & $.237^{* *}$ & $.202^{* *}$ & $.218^{* *}$ & $.245^{* *}$ & -.018 & $.183^{*}$ \\
\hline CUL9 & $-.102^{*}$ & -.033 & $.274^{* *}$ & $.417^{* *}$ & $.544^{* *}$ & $.552^{* *}$ & $.515^{* *}$ & $.548^{* *}$ & .026 & $.497^{* *}$ \\
\hline
\end{tabular}

Note: ${ }^{\star} \mathrm{p}<0.05 ;{ }^{\star *} \mathrm{p}<0.01$.

\subsection{Regression analysis}

Table 3 presents the results of the regression analysis, with the predictive effect of the organizational culture dimensions (independent variables) on the CMPR dimensions and the OPR dimensions (dependent variables). This was examined using multiple regression analysis.

Table 3. Regression analysis (independent variables: the organizational culture dimensions; dependent variables: the CMPR dimensions and the OPR dimensions)

\begin{tabular}{|l|c|c|c|c|c|c|c|c|c|c|c|c|}
\hline Dep. & CUL1 & CUL2 & CUL3 & CUL4 & $\begin{array}{c}\text { Indep. } \\
\text { CUL5 } \\
\beta\end{array}$ & CUL6 & CUL7 & CUL8 & CUL9 & R $^{2}$ & F & Sig. \\
\hline MOD1 & -.002 & -.212 & $\mathbf{. 2 4 3}$ & .112 & -.113 & .065 & .024 & -.021 & .051 & $\mathbf{0 . 0 9 8}$ & 4.843 & .000 \\
\hline MOD2 & .034 & -.036 & $\mathbf{. 2 8 1}$ & .106 & -.052 & .021 & -.057 & -.067 & .077 & $\mathbf{0 . 0 9 1}$ & 4.475 & .000 \\
\hline MOD3 & .031 & $\mathbf{. 1 7 9}$ & .051 & $\mathbf{. 1 8 7}$ & -.058 & -.101 & .091 & $\mathbf{. 1 1 9}$ & .099 & $\mathbf{0 . 1 6 2}$ & 8.653 & .000 \\
\hline MOD4 & .088 & .083 & -.039 &. $\mathbf{2 0 0}$ & .015 & -.083 & $\mathbf{. 1 7 5}$ & $\mathbf{. 1 0 3}$ & $\mathbf{. 1 2 5}$ & $\mathbf{0 . 2 9 3}$ & 18.586 & .000 \\
\hline REL1 & .041 & .081 & -.019 & .064 & $\mathbf{. 1 2 5}$ & $\mathbf{. 1 4 6}$ & $\mathbf{. 2 5 1}$ & $\mathbf{. 0 8 3}$ & .050 & $\mathbf{0 . 4 7 9}$ & 41.141 & .000 \\
\hline REL2 & .074 & $\mathbf{. 1 2 1}$ & -.011 & .062 & .065 & $\mathbf{. 1 4 9}$ & $\mathbf{. 2 6 2}$ & .041 & .063 & $\mathbf{0 . 4 8 4}$ & 41.984 & .000 \\
\hline REL3 &. $\mathbf{1 1 9}$ & .095 & -.016 & $\mathbf{. 1 3 3}$ & -.026 & .018 & $\mathbf{. 2 8 3}$ & $\mathbf{. 0 7 9}$ & $\mathbf{. 1 2 0}$ & $\mathbf{0 . 4 1 4}$ & 31.649 & .000 \\
\hline REL4 & $\mathbf{. 1 1 7}$ & $\mathbf{. 1 0 5}$ & -.009 & $\mathbf{. 1 1 4}$ & .092 & .018 & $\mathbf{. 2 1 4}$ & $\mathbf{. 0 9 5}$ & $\mathbf{. 1 2 9}$ & $\mathbf{0 . 4 6 2}$ & 38.507 & .000 \\
\hline REL5 & -.008 & .029 & $\mathbf{. 2 1 6}$ & -.012 & .033 & -.005 & -.115 & -.027 & $\mathbf{. 1 6 2}$ & $\mathbf{0 . 0 5 6}$ & 2.656 & .005 \\
\hline REL6 & $\mathbf{. 1 4 3}$ & -.004 & $\mathbf{- . 1 2 4}$ & .001 & .017 & -.052 & $\mathbf{. 3 5 7}$ & .083 & $\mathbf{. 1 6 5}$ & $\mathbf{0 . 3 8 2}$ & 27.647 & .000 \\
\hline
\end{tabular}

\subsection{National origin of companies and their moderating effects}

Table 4 shows the correlation coefficients between the organizational culture dimensions and the CMPR dimensions and the OPR dimensions, especially for Serbian and foreign companies, are shown in. The sample included 252 domestic (Serbian) companies $\left(\mathrm{N}_{\mathrm{DOM}}=252\right)$ and 163 foreign companies $\left(\mathrm{N}_{\mathrm{FOR}}=163\right)$. 
Table 4. Correlation coefficients between the organizational culture dimensions and the CMPR dimensions and the OPR dimensions, for domestic companies (DOM) and foreign companies (FOR)

\begin{tabular}{|c|c|c|c|c|c|c|c|c|c|c|c|}
\hline NoC & & MOD1 & MOD2 & MOD3 & MOD4 & REL1 & REL2 & EL3 & REL4 & EL5 & REL6 \\
\hline & CUL1 & -.013 & .009 & $.267^{* *}$ & $.381^{* *}$ & $.443^{* *}$ & $.433^{* *}$ & $.419^{* *}$ & $.434^{* *}$ & -.025 & $.414^{* *}$ \\
\hline & CUL2 & $231^{* *}$ & $-.155^{\star}$ & $.352^{* *}$ & $.494^{* *}$ & $.567^{* *}$ & $.587^{* *}$ & $.535^{* *}$ & $.546^{* *}$ & -.070 & $.462^{* *}$ \\
\hline & CUL3 & $.203^{* *}$ & $.309^{* *}$ & $-.171^{* *}$ & $-.325^{* *}$ & $-.438^{* *}$ & $-.443^{* *}$ & $-.392^{* *}$ & $-.368^{* *}$ & $.172^{* *}$ & $-.433^{* *}$ \\
\hline \multirow{9}{*}{ DOM } & CUL4 & -.103 & -.067 & $.326^{* *}$ & $.516^{* *}$ & $.531^{* *}$ & $.529^{* *}$ & $.532^{* *}$ & $.556^{* *}$ & -.074 & $.474^{* *}$ \\
\hline & CUL5 & $-.237^{* *}$ & $-.188^{* *}$ & $.265^{* *}$ & $.459^{* *}$ & $.624^{* *}$ & $.604^{* *}$ & $.525^{* *}$ & $.590^{\star *}$ & $-.131^{*}$ & $.492^{* *}$ \\
\hline & CUL6 & $-.226^{* *}$ & $-.239^{* *}$ & $.269^{* *}$ & $.470^{* *}$ & $.673^{* *}$ & $.677^{* *}$ & $.579^{* *}$ & $.588^{\star *}$ & $-.125^{*}$ & $.542^{* *}$ \\
\hline & CUL7 & $-.208^{* *}$ & $-.163^{* *}$ & $.332^{* *}$ & $.528^{* *}$ & $.690^{* *}$ & $.683^{* *}$ & $.608^{* *}$ & $.636^{* *}$ & $-.152^{*}$ & $.605^{* *}$ \\
\hline & CUL8 & -.037 & -.056 & $.194^{* *}$ & $.213^{* *}$ & $.252^{* *}$ & $.203^{* *}$ & $.231^{* *}$ & $.249^{* *}$ & -.056 & $.161^{*}$ \\
\hline & CUL9 & $-.142^{*}$ & -.095 & $.276^{* *}$ & $.474^{* *}$ & $.595^{* *}$ & $.597^{* *}$ & $.557^{* *}$ & $.599^{\star *}$ & .005 & $.509^{* *}$ \\
\hline & CUL1 & -.143 & .071 & $.164^{*}$ & $.230^{* *}$ & $.263^{* *}$ & $.379^{* *}$ & $.400^{* *}$ & $.416^{* *}$ & .058 & $.270^{* *}$ \\
\hline & CUL2 & -.134 & .094 & $.279^{* *}$ & $.288^{* *}$ & $.458^{* *}$ & $.506^{* *}$ & $.490^{* *}$ & $.543^{\star *}$ & .099 & $.402^{* *}$ \\
\hline & CUL3 & $.309^{* *}$ & $.206^{* *}$ & . 133 & -.029 & -.138 & -.094 & -.074 & -.151 & $.213^{* *}$ & $-.170^{*}$ \\
\hline \multirow{6}{*}{ FOR } & CUL4 & .003 & .095 & $.291^{* *}$ & $.335^{* *}$ & $.514^{* *}$ & $.530^{* *}$ & $.489^{* *}$ & $.500^{* *}$ & .024 & $.324^{* *}$ \\
\hline & CUL5 & -.031 & .053 & $.191^{*}$ & $.369^{* *}$ & $.584^{* *}$ & $.584^{* *}$ & $.520^{* *}$ & $.572^{* *}$ & .102 & $.543^{* *}$ \\
\hline & CUL6 & -.033 & .143 & $.211^{* *}$ & $.337^{* *}$ & $.544^{* *}$ & $.538^{\star *}$ & $.504^{* *}$ & $.569^{* *}$ & .048 & $.484^{* *}$ \\
\hline & CUL7 & -.077 & -.004 & $.205^{* *}$ & $.384^{* *}$ & $.591^{* *}$ & $.616^{* *}$ & $.582^{* *}$ & $.610^{\star *}$ & .074 & $.547^{* *}$ \\
\hline & CUL8 & -.047 & -.049 & $.219^{* *}$ & $.200^{*}$ & $.214^{* *}$ & $.201^{\star *}$ & $.199^{*}$ & $.239^{* *}$ & .040 & $.230^{* *}$ \\
\hline & CUL9 & -.022 & .074 & $.246^{* *}$ & $.289^{* *}$ & $.438^{* *}$ & $.462^{* *}$ & $.455^{* *}$ & $.474^{* *}$ & .077 & $.465^{* \star}$ \\
\hline
\end{tabular}

Note: ${ }^{*} \mathrm{p}<0.05 ;{ }^{* *} \mathrm{p}<0.01$.

The moderating effects of the companies' national origin in the relation of the organizational culture dimension and the CMPR dimensions and the OPR dimensions were shown using hierarchical regression analysis. Table 5 shows the results of these tests. In this table, only the results for couples with moderating effects are shown: R square change and F-change values in these cases, as well as correlations of the given pairs for both relevant groups (domestic and foreign companies).

Table 5. Hierarchical regression analysis of the moderating effects of National origin of companies in observed relations (only the results where there are moderating effects)

\begin{tabular}{|c|c|c|c|c|c|c|}
\hline \multirow{2}{*}{ Number } & \multirow{2}{*}{ Ind. } & \multirow{2}{*}{ Dep. } & \multirow{2}{*}{$\begin{array}{c}\text { R square } \\
\text { change }\end{array}$} & F-change & \multicolumn{2}{|c|}{\begin{tabular}{c} 
Correlations \\
\cline { 5 - 7 }
\end{tabular}} \\
& & & & & $\begin{array}{c}\text { Domestic } \\
\mathrm{N}_{\text {DOM }}=252\end{array}$ & $\begin{array}{c}\text { Foreign } \\
\mathrm{N}_{\text {FOR }}=163\end{array}$ \\
\hline 1 & CUL1 & MOD4 & 0.008 & 3.655 & $.381^{* *}$ & $.230^{* *}$ \\
\hline 2 & CUL1 & REL1 & 0.011 & 5.113 & $.443^{* *}$ & $.263^{* *}$ \\
\hline 3 & CUL1 & REL6 & 0.010 & 4.755 & $.414^{* *}$ & $.270^{* *}$ \\
\hline 4 & CUL2 & MOD2 & 0.014 & 6.073 & $-.155^{*}$ & .094 \\
\hline 5 & CUL2 & MOD4 & 0.012 & 6.106 & $.494^{* *}$ & $.288^{* *}$ \\
\hline 6 & CUL3 & MOD3 & 0.021 & 9.118 & $-.171^{* *}$ & .133 \\
\hline
\end{tabular}


End of Table 5

\begin{tabular}{|c|c|c|c|c|c|c|}
\hline \multirow{2}{*}{ Number } & \multirow{2}{*}{ Ind. } & \multirow{2}{*}{ Dep. } & \multirow{2}{*}{$\begin{array}{c}\text { R square } \\
\text { change }\end{array}$} & F-change & \multicolumn{2}{|c|}{ Correlations } \\
\cline { 6 - 7 } & & & & $\begin{array}{c}\text { Domestic } \\
\mathrm{N}_{\text {DOM }}=252\end{array}$ & $\begin{array}{c}\text { Foreign } \\
\mathrm{N}_{\text {FOR }}=163\end{array}$ \\
\hline 7 & CUL3 & MOD4 & 0.021 & 9.417 & $-.325^{* *}$ & -.029 \\
\hline 8 & CUL3 & REL1 & 0.022 & 10.513 & $-.438^{* *}$ & -.138 \\
\hline 9 & CUL3 & REL2 & 0.031 & 14.537 & $-.443^{* *}$ & -.094 \\
\hline 10 & CUL3 & REL3 & 0.020 & 9.235 & $-.392^{* *}$ & -.074 \\
\hline 11 & CUL3 & REL4 & 0.009 & 4.226 & $-.368^{* *}$ & -.151 \\
\hline 12 & CUL3 & REL6 & 0.020 & 9.737 & $-.433^{* *}$ & $-.170^{*}$ \\
\hline 13 & CUL4 & MOD4 & 0.009 & 7.893 & $.516^{* *}$ & $.335^{* *}$ \\
\hline 14 & CUL4 & REL6 & 0.009 & 4.618 & $.474^{* *}$ & $.324^{* *}$ \\
\hline 15 & CUL5 & MOD1 & 0.008 & 3.324 & $-.237^{* *}$ & -.031 \\
\hline 16 & CUL5 & MOD2 & 0.013 & 5.309 & $-.188^{* *}$ & .053 \\
\hline 17 & CUL5 & REL5 & 0.012 & 5.128 & $-.131^{*}$ & .102 \\
\hline 18 & CUL6 & MOD2 & 0.032 & 13.698 & $-.239^{* *}$ & .143 \\
\hline 19 & CUL7 & REL5 & 0.011 & 4.415 & $-.152^{*}$ & .074 \\
\hline
\end{tabular}

\section{Discussion}

\subsection{The correlation analysis - checking $\mathrm{H} 1$}

Table 2 shows that in most cases the organizational culture dimensions have a statistically significant and positive impact on the PR dimensions. Thus, hypothesis $\mathrm{H} 1$ is confirmed. At the same time, these results show a similarity with those gained in previous research into the impact of organizational culture on PR, for example (Sriramesh et al., 1996; Harris et al., 1999; Curtin, 2008; Erzikova \& Berger, 2016; Yeo \& Pang, 2017; Thurlow et al., 2017).

From the organizational culture dimensions, CUL7 - Collectivism 2 (In group) has the strongest impact. This dimension of organizational culture is comprised of items such as employee loyalty to the organization, employee pride because of working for the organization, manager pride in individual employee achievements, and, finally, organization loyalty towards employees. An organization that places value on these aspects of social relations within its framework is very likely to apply two-way communication models, especially the symmetrical model (the strongest positive correlation in influencing the CMPR dimensions is between the dimensions CUL7 - Collectivism 2 and MOD4 - Two-way Symmetrical). Likewise, internal, mutual loyalty between the organization and employees is mapped to external loyalty between the organization and the public. Then there are strong positive correlations with most of the OPR dimensions. Practically, this means that in such conditions, there is appreciation of public opinion from the organization, a fair attitude from the organization to the public, the realization of long-term duties on the part of the organization, and the satisfaction of the public in working with the organization as well as the honest, benevolent external action of the organization. 
Most other organizational culture dimensions have a similar impact, particularly the dimensions CUL6 - Performance Orientation, CUL5 - Humane Orientation, and then CUL2 Future Oriented, CUL9 - Assertiveness and CUL4 - Collectivism 1. Generally, a favorable organizational culture, presented through loyalty between the organization and its employees, fostering efficiency and performance enhancement, nurturing quality interpersonal relationships, planning for the future, fostering collective loyalty, and such like, has a positive impact on two-way communication models, especially the symmetrical model, as well as most of the OPR dimensions. Exceptions to this kind of organizational culture exist for two dimensions of CMPR (MOD1 - Public Information and MOD2 - Press Agentry) and one dimension of the OPR dimensions (REL5 - Exchange Relationship). The aforementioned three dimensions have largely negative, often statistically significant correlations with most of the organizational culture dimensions. This means that an unfavorable organizational culture, lacking the above desirable elements, creates the conditions for the use of one-way communication, the concealment of unfavorable information, a lack of mediation between the management and the public, a focus on avoiding negative publicity, and the orientation of the organization solely for its own benefit and short-term effects. These results can be considered consistent with those of the references (Cameron \& McCollum, 1993; Seltzer et al., 2012), which identified a link between two-way symmetrical communication and favorable organizational culture.

A total exception to the previously described influences of the organizational culture dimensions occurs for dimension CUL3 - Power Distance. This dimension acts in the opposite way: it has significant and statistically positive effect on the dimensions MOD1 - Public Information, MOD2 - Press Agentry and REL5 - Exchange Relationship, and a negative and in most cases statistically significant effect on the other dimensions. The high power distance in an organization seems to impede two-way communication, especially symmetrical communication. Similarly, an increased power distance drives the organization into behavior that does not respect public opinion, lacks fair relations regarding the public and neglects continuing public service responsibilities. Therefore, the existence of a high power distance in an organization is also reflected on the external plane, as a rule by the public recognizing the power distance as a negative phenomenon. This is accompanied by a lack of public confidence in the organization, reduced public satisfaction with the organization, as well as doubts about the organization's sincerity. In contrast, a high power distance encourages oneway communication and directs the organization's focus to its own advantage. This is logical given the very nature of the power distance in organizations and society: unequal distribution of power, focus on authority, the power and benefits enjoyed by a narrow circle of individuals, and the absence of equal relations.

From the CMPR dimensions and the OPR dimensions, the dimensions REL2 - Trust, followed by REL1 - Control Mutuality, REL4 - Satisfaction and REL3 - Commitment are under the strongest influence of the organizational culture dimensions. Thus, a companies' organizational culture is strongly mirrored in the relationships of that organization and its target publics. In this way, organizational culture goes beyond the organization itself and acquires an external character and significance. Practically, the organizational culture of an organization will greatly depend on the attitude of that organization towards the target pub- 
lic, as well as the relationship of the target public with that organization. A similar result can be seen in the reference (Wang \& Chaudhri, 2009), which emphasizes the importance of corporate social responsibility and its connection with organizational culture. Ultimately, it has been demonstrated here that a favorable organizational culture engenders greater public trust, public satisfaction, and public commitment to further collaboration. It should also be noted that from the CMPR dimensions, the strongest (positive) correlations exist with the MOD4 dimension - Two-way Symmetrical.

On the other hand, the dimensions under the weakest influence of the dimensions of organizational culture are REL5 - Exchange Relationship, then MOD2 - Press Agentry and MOD1 - Public Information. These three dimensions have mostly negative correlations, except for the CUL3 - Power Distance dimension, which was discussed earlier. A negative (statistically significant) impact exists on the MOD1 dimension - Public Information. Thus, a favorable organizational culture will diminish the chances of the neutral provision of information, the concealment of unfavorable information, a biased evaluation of PR activities, a lack of mediation between management and the public, and the like.

Based on the aforementioned, it is easy to conclude that organizational culture has a greater impact on the OPR dimensions than on the CMPR dimensions. The OPR reflect more closely and more directly the philosophy of the organization, social relations and the way the organization works (in other words, the organizational culture), than the CMPR themselves. The CMPR are, in a way, a tool for realizing communication and relations between organizations and the public. It can be said that the connection between organizational culture and OPR is essential, while that between organizational culture and CMPR is technical, or instrumental.

\subsection{The regression analysis - checking $\mathrm{H} 2$}

The results of the regression analysis are shown in Table 3, in order to explore the predictive effects of the organizational culture dimensions on the CMPR dimensions and the OPR dimensions. The CUL7 - Collectivism 2 (In group) dimension has the strongest predictive effect, a result that is consistent with the results of the correlation analysis. In light of this, the explanation is analogous. The predictive effects of the other organizational culture dimensions are fairly evenly distributed. At the same time, the results are compatible with that gain in the correlation analysis. For example, the CUL3 - Power Distance dimension has a statistically significant and positive predictive effect on MOD1 - Public Information, MOD2 - Press Agentry and REL5 - Exchange Relationship.

There is a difference in a slightly lower predictive effect of the CUL5 dimension - Humane Orientation, as well as the enhanced predictive effect of the CUL8 dimension - Gender Egalitarianism. Based on this result, it is clear that gender equality in the organization, the equal distribution of men and women in leadership positions, as well as equal conditions and incentives for advancement, are certainly of significance and exert an influence on establishing two-way communication and organization - public quality relations. In addition, while the CUL9 - Assertiveness dimension showed statistically significant effects in the correlation analysis, the regression analysis has further highlighted the predictive 
effect of this dimension. It is interesting to note that between the CUL9 - Assertiveness dimension on the REL5 - Exchange Relationship dimension exists a statistically significant and positive predictive effect. Although the correlation analysis did not show any statistically significant correlation between the two dimensions, in the regression analysis, due to the effect of a number of independent variables, the predictive effect of the CUL9 - Assertiveness dimension turned out to be both statistically significant and positive. This means that the pronounced presence of assertiveness in an organization may result in improved relations between the organization and its target public, based primarily on the interests of and benefits to the organization.

According to Table $3, \mathrm{R}^{2}$ have relatively high and statistically significant values, ranging from 0.056 to 0.484 . Hypothesis $\mathrm{H} 2$ is thus confirmed. Observed in terms of the individual dependent variables (the CMPR dimensions and the OPR dimensions), those dimensions under the strongest predictive effect of the organizational culture dimensions are REL2 Trust, followed by REL1 - Control Mutuality, REL4 - Satisfaction and REL3 - Commitment. On the other hand, the dimensions of REL5 - Exchange Relationship, followed by MOD2 - Press Agentry and MOD1 - Public Information are under the weakest predictive effect of the organizational culture dimensions. The findings shown here are completely in accordance with those shown by the correlation analysis.

\subsection{The company's national origin as a moderator- answer to RQ}

The results of examining the moderating effects of the company's national origin on the observed relationships can be seen in Tables 4 and 5. Based on the results obtained, it can be concluded that company's national origin as a moderator exists in a number of cases and is expressed as the average. This answers our RQ. Generally, when considering this moderating effect, the correlations are significantly stronger for domestic (Serbian) companies. The overall conclusion is that organizational culture has a greater impact on public relations in Serbian companies than in their foreign counterparts. This phenomenon can be explained by the greater presence and importance placed on public relations in foreign companies. It may also be linked to the longer tradition and more standard approach of public relations in foreign companies than in Serbian ones. In foreign companies, where the way PR functions is established based on certain standards, organizational culture has little influence on the choice of the CMPR and the way in which the OPR is realized.

This is especially true for the influence of the CUL3 - Power Distance dimension and the CUL5 - Humane Orientation dimension. In Serbian companies, high power distance adversely affects two-way communication and the OPR. Likewise, in Serbian companies, low people orientation can significantly encourage the establishment of one-way communication, as well as the organization's dominant orientation towards its own interests and benefits. From the CMPR and the OPR dimensions, the moderating effect described is most strongly manifested for the MOD4 - Two-way Symmetrical, REL6 - Communal Relationship and MOD2 - Press Agentry dimensions. 


\section{Conclusions}

In most cases, the organizational culture dimensions have a statistically significant and positive impact on the CMPR dimensions and the OPR dimensions. In doing so, there is a greater impact on the OPR dimensions than on the CMPR dimensions. CUL7 - Collectivism 2 (In group) has the strongest impact, but all the other dimensions also have a strong impact. Thus, internal loyalty between the organization and its employees is transferred to external loyalty between the organization and the public. In general, a favorable organizational culture (represented through the favorable values of the organizational culture dimensions) has a positive impact on two-way communication models, especially the symmetrical model, as well as on most of the OPR dimensions. At the same time, a favorable organizational culture has a negative impact on three dimensions: MOD1 - Public Information, MOD2 - Press Agentry and REL5 - Exchange Relationship. It follows that an unfavorable organizational culture (represented through the unfavorable values of the dimensions of organizational culture) encourages one-way communication and the organization's orientation solely for its own benefit.

Given that high power distance is a characteristic of an unfavorable organizational culture, it is important to emphasize that the CUL3 - Power Distance dimension works in contrast to the other organizational culture dimensions: high power distance impedes twoway communication, leading to the organization's lack of respect for public opinion, and the absence of fair relations toward the public. This causes certain negative reactions from the public towards the organization: mistrust, doubt in its sincerity, dissatisfaction, rethinking of long-term relationships.

An examination of the moderating effect of a company's national origin has shown that organizational culture has a greater impact on public relations in Serbian companies than in foreign ones. Foreign companies have a longer tradition in the realization of public relations, which means continuity, greater persistence, and a more established and set functioning of the PR service. In such stable conditions, organizational culture does not have as much influence on public relations, or more precisely, it does not have as much influence on the choice of the CMPR and the way of realizing the OPR. The impact of the CUL3 - Power Distance dimension is again emphasized here, because in Serbian companies the high power distance has an extremely adverse effect on two-way communication and the OPR.

The significance of this study is that the influence of individual dimensions of organizational culture on the dimensions of PR (CMPR dimensions and OPR dimensions) has been determined. In this way, the directions and strengths of the interconnections between the precisely defined dimensions are viewed more accurately. Also, introducing the analysis of the moderating effect of company's national origin showed the differences in the way the organizational culture impacts on public relations in Serbian and foreign companies operating in Serbia. One of the limitations of the research may be that the results obtained relate primarily to Serbia and specific transitional conditions. Nevertheless, it can be assumed that similar relationships between the observed dimensions exist in other countries, especially those countries which share similar economic and social conditions.

The general recommendation for leaders and managers is to continually strive for the improvement of organizational culture, thus creating more favorable conditions for the 
implementation of two-way symmetrical communication and the establishment of highquality OPR. In particular, it is necessary to develop internal trust and loyalty between the organization and its employees, increase the concern for people, foster good interpersonal relations and gender equality in the organization, continuously improve performance and efficiency, and plan for the future. Most importantly, external communication and OPR can be significantly improved by establishing and maintaining a low power distance within the organization. All of these recommendations apply primarily to organizations and leaders in Serbia, but because of their universality, they may be applicable under general conditions.

The limitation of the research can be found in the fact that the obtained results present the situation in Serbia. Nevertheless, similar relationships of the observed dimensions can be expected to exist in other countries, especially in those with similar levels of economic and social development. The proposal for further research is to examine the impact of leadership on public relations practice, and then to examine the impact of public relations practice on job satisfaction and organizational commitment, employee trust at work, and similar. It is also possible to examine the opposite direction of influence: how public relations can act to create a more favorable (desirable) organizational culture in organizations.

\section{Funding}

There was no funding.

\section{Author contributions}

Edit Terek Stojanović, Milan Nikolić and Marko Vlahović conceived the study and were responsible for the design and development of the data analysis. Marko Vlahović, Siniša Mitić and Zoran Jovanović were responsible for data collection and analysis. Edit Terek Stojanović and Milan Nikolić were responsible for data interpretation.

\section{Disclosure statement}

The authors have no competing financial, professional, or personal interests from other parties.

\section{References}

Berger, B. K., \& Reber, B. H. (2006). Gaining influence in public relations: The role of resistance in practice. Lawrence Erlbaum. https://doi.org/10.4324/9781410616975

Bhalla, N., \& Overton, H. (2019). Examining cultural impacts on consumers' environmental CSR outcomes. Corporate Communications: An International Journal, 24(3), 569-592. https://doi.org/10.1108/CCIJ-09-2018-0094

Black, S. (1993). The essential of public relations. Kogan Page Limited.

Calori, R., \& Sarnin, P. (1991). Corporate culture and economic performance: A French study. Organizational Studies, 12, 49-74. https://doi.org/10.1177/017084069101200104 
Cameron, G. T., \& McCollum, T. (1993). Competing corporate cultures: A multi-method, cultural analysis of the role of internal communication. Journal of Public Relations Research, 5(4), 217-250. https://doi.org/10.1207/s1532754xjprr0504_01

Chen, X., Hung-Baesecke, C., \& Chen, Y. R. (2020). Constructing positive public relations in China: Integrating public relations dimensions, dialogic theory of public relations and the Chinese philosophical thinking of Yin and Yang. Public Relations Review, 46(1), 101770. https://doi.org/10.1016/j.pubrev.2019.04.004

Curtin, P. (2008). Fred Harvey Company public relations and publicity (1876-1933). Journal of Communication Management, 12(4), 359-373. https://doi.org/10.1108/13632540810919819

Deal, T. E., \& Kennedy, A. A. (1982). Corporate cultures: the rites and rituals of corporate life. Penguin Books. https://doi.org/10.1016/0007-6813(83)90092-7

Dhanesh, G. S., \& Duthler, G. P. (2019). Public relations in the Middle East: an editorial introduction. Journal of Public Relations Research, 31(3-4), 71-83.

https://doi.org/10.1080/1062726X.2019.1679436

Dhanesh, G. S., \& Sriramesh, K. (2018). Culture and crisis communication: Nestle India’s Maggi Noodles case. Journal of International Management, 24(3), 204-214. https://doi.org/10.1016/j.intman.2017.12.004

Erzikova, E., \& Berger, B. K. (2016). Gender effect in Russian public relations: a perfect storm of obstacles for women. In Women's Studies International Forum, 56, 28-36. https://doi.org/10.1016/j.wsif.2016.02.011

Erzikova, E., Waters, R., \& Bocharsky, K. (2018). Media catching: a conceptual framework for understanding strategic mediatization in public relations? International Journal of Strategic Communication, 12(2), 145-159. https://doi.org/10.1080/1553118X.2018.1424713

Gordon, A. E. (2011). Public relations. Oxford University Press.

Grunig, J. E., Grunig, L. A., Sriramesh, K., Huang, Y. H., \& Lyra, A. (1995). Models of public relations in an international setting. Journal of Public Relations Research, 7(3), 163-186. https://doi.org/10.1207/s1532754xjprr0703_01

Grunig, J. E., \& Hunt, T. (1984). Managing public relations. Holt, Rinehart and Winston.

Harris, P., Ziegler-Pierce, S., \& Harris, I. (1999). The impact of organisational culture research on the practice of public relations by regional television. Journal of Communication Management, 4(1), 43-55. https://doi.org/10.1108/eb023506

Hofstede, G. (2001). Culture's consequences, comparing values, behaviors, institutions, and organizations across nations. Sage Publications.

Hofstede, G. (1998). Attitudes, values, and organizational culture: disentangling the concepts. Organization Studies, 19(3), 477-493. https://doi.org/10.1177/017084069801900305

Hofstede, G. (1991). Cultures and organizations: software of the mind. McGraw-Hill.

Hon, L. C., \& Grunig, J. E. (1999). Guidelines for measuring relationships in public relations. Institute for Public Relations.

House, R. J., Hanges, P. J., Javidan, M., Dorfman, P. W., \& Gupta, V. (2004). Leadership, culture, and organizations: The GLOBE study of 62 societies. Sage.

House, R. J., Javidan, M., Hanges, P., \& Dorfman, P. (2002). Understanding cultures and implicit leadership theories across the globe: An introduction to project GLOBE. Journal of World Business, 37(1), 3-10. https://doi.org/10.1016/S1090-9516(01)00069-4

House, R. J., Javidan, M., \& Dorfman, P. (2001). Project GLOBE: an introduction. Applied Psychology: An International Review, 50(4), 489-505. https://doi.org/10.1111/1464-0597.00070

House, R. J., Hanges, P. J., Ruiz-Quintanilla, S. A., Dorfman, P. W., Falkus, S. A., \& Ashkanasy, N. M. (1999). Cultural influences on leadership and organizations: Project GLOBE. In W. H. Mobley, 
M. J. Gessner, \& V. Arnold (Eds.), Advances in global leadership (2 ed., pp. 171-233). Emerald Group Publishing Ltd.

House, R., Wright, N. S., \& Aditya, R. N. (1997). Cross-cultural research on organizational leadership: a critical analysis and proposed theory. In P. C. Early \& M. Erez (Eds.), New perspectives on international industrial/organizational psychology (pp. 535-625). Lexington Press.

Javidan, M., \& House, R. J. (2001). Cultural acumen for the global manager: Lessons from project GLOBE. Organizational Dynamics, 29(4), 289-305. https://doi.org/10.1016/S0090-2616(01)00034-1

Javidan, M., House, R. J., \& Dorfman, P. W. (2004). A nontechnical summary of GLOBE findings. In R. J. House, P. J. Hanges, M. Javidan, P. W. Dorfman, \& V. Gupta (Eds.), Culture, leadership, and organizations: The GLOBE study of 62 societies (pp. 29-48). Sage.

Johnston, K. A., \& Everett, J. L. (2012). Employee perceptions of reputation: an ethnographic study. Public Relations Review, 38(4), 541-554. https://doi.org/10.1016/j.pubrev.2012.05.007

Judge, T. A., Thoresen, C. J., Bono, J. E., \& Patton, G. K. (2001). The job satisfaction - job performance relationship: a qualitative and quantitative review. Psychological Bulletin, 127, 376-407. https://doi.org/10.1037/0033-2909.127.3.376

Kotter, J., \& Heskett, J. L. (1992). Corporate culture and performance. The Free Press.

Lumbar Globočnik, K., Žnidaršič, A., \& Ferjan, M. (2019). Relationship between Russian societal culture and public relations strategies. Journal for East European Management Studies, 24(3), 375-397. https://doi.org/10.5771/0949-6181-2019-3-375

Martinelli, D., \& Erzikova, E. (2017). Public relations leadership development cycle: A cross-cultural perspective. Public Relations Review, 43(5), 1062-1072. https://doi.org/10.1016/j.pubrev.2017.09.002

Men, L., \& Jiang, H. (2016). Cultivating quality employee-organization relationships: the interplay among organizational leadership, culture, and communication. International Journal of Strategic Communication, 10(5), 462-479. https://doi.org/10.1080/1553118X.2016.1226172

Meng, J. (2014). Cultural congruence or difference: a paired country investigation of leadership effectiveness in public relations. The Journal of International Communication, 20(1), 52-76. https://doi.org/10.1080/13216597.2013.876438

Meng, J., \& Berger, B. K. (2019). The impact of organizational culture and leadership performance on PR professionals' job satisfaction: testing the joint mediating effects of engagement and trust. Public Relations Review, 45(1), 64-75. https://doi.org/10.1016/j.pubrev.2018.11.002

Moynihan, D. P., \& Pandey, S. K. (2007). Finding workable levers over work motivation: Comparing job satisfaction, job involvement, and organizational commitment. Administration \& Society, 39(7), 803-832. https://doi.org/10.1177/0095399707305546

Ogbonna, E., \& Harris, L. C. (2000). Leadership style, organizational culture and performance: Empirical evidence from UK companies. The International Journal of Human Resource Management, 11(4), 766-788. https://doi.org/10.1080/09585190050075114

O'Reilly, C. A. III, Chatman, J., \& Caldwell, D. F. (1991). People and organizational culture: a profile comparison approach to assessing person-organization fit. Academy of Management Journal, 34(3), 487-516. https://doi.org/10.2307/256404

Pacanowsky, M., \& O’Donell-Trujillo, N. (1982). Communication and organizational culture. The Western Journal of Speech Communication, 46(2), 115-130. https://doi.org/10.1080/10570318209374072

Penning, T. (2011). The value of public relations in investor relations: individual investors' preferred information types, qualities, and sources. Journalism \& Mass Communication Quarterly, 88(3), 615-631. https://doi.org/10.1177/107769901108800309

Rajković, J., Nikolić, M., Ćoćkalo, D., Terek, E., \& Božić, S. (2020). National culture and the entrepreneurial intentions of students in Serbia. Journal for East European Management Studies, 25(1), 105-141. https://doi.org/10.5771/0949-6181-2020-1-105 
Schein, E. H. (1985). Organizational culture and leadership: a dynamic view. Jossey-Bass Publishers.

Seltzer, T., Gardner, E., Bichard, S., \& Callison, C. (2012). PR in the ER: Managing internal organization-public relationships in a hospital emergency department. Public Relations Review, 38(1), 128-136. https://doi.org/10.1016/j.pubrev.2011.12.002

Sriramesh, K., Grunig, J. E., \& Dozier, D. M. (1996). Observation and measurement of two dimensions of organizational culture and their relationship to public relations. Journal of Public Relations Research, 8(4), 229-261. https://doi.org/10.1207/s1532754xjprr0804_02

Sriramesh, K., \& Verčič, D. (2009). A theoretical framework for global public relations research and practice. In K. Sriramesh \& D. Vercic (Eds.), The global public relations handbook: Theory, research and practice (2nd ed., pp. 3-21). Routledge. https://doi.org/10.4324/9780203889374

Sriramesh, K., \& Verčič, D. (2019). The global public relations handbook: theory, research and practice (3rd ed.). Routledge. https://doi.org/10.4324/9781315173290

Thurlow, A., Kushniryk, A., Yue, A. R., Blanchette, K., Murchland, P., \& Simon, A. (2017). Evaluating excellence: a model of evaluation for public relations practice in organizational culture and context. Public Relations Review, 43(1), 71-79. https://doi.org/10.1016/j.pubrev.2016.10.013

Vance, L., Raciti, M., \& Lawley, M. (2016). Sponsorship selections: corporate culture, beliefs and motivations. Corporate Communications: An International Journal, 21(4), 483-499. https://doi.org/10.1108/CCIJ-11-2015-0072

Vasquez, G. M., \& Taylor, M. (2000). What cultural values influence American public relations practitioners? Public Relations Review, 25(4), 433-449. https://doi.org/10.1016/S0363-8111(99)00030-2

Verhoeven, P., Zerfass, A., Verčič, D., Tench, R., \& Moreno, A. (2018). Public relations and the rise of hypermodern values: exploring the profession in Europe. Public Relations Review, 44(4), 471-480. https://doi.org/10.1016/j.pubrev.2018.06.001

Wang, J., \& Chaudhri, V. (2009). Corporate social responsibility engagement and communication by Chinese companies. Public Relations Review, 35(3), 247-250. https://doi.org/10.1016/j.pubrev.2009.04.005

Weihrich, H., \& Koontz, H. (1998). Management (11th ed.). Mate.

Wilcox, D. L., \& Cameron, G. T. (2009). Public relations (9th ed.). Allyn \& Bacon.

Windahl, S., Signitzer, B. H., \& Olson, J. T. (2009). Using communication theory: an introduction to planned communication (2nd ed.). Sage Publications.

Yeo, S. L., \& Pang, A. (2017). Asian multiculturalism in communication: impact of culture in the practice of public relations in Singapore. Public Relations Review, 43(1), 112-122.

https://doi.org/10.1016/j.pubrev.2016.10.014 